\title{
The type of anticoagulant used for plasma collection affects in vitro Rhodococcus equi assays
}

\author{
Alejandra A. Rivolta', Dana C. Pittman ${ }^{1}$, Amanda J. Kappes ${ }^{1}$, Robert K. Stancil ${ }^{2}$, Clark Kogan² and \\ Macarena G. Sanz ${ }^{1 *}$ (I)
}

\begin{abstract}
Objective: The efficacy of Rhodococcus equi-specific hyperimmune plasma (HIP) is usually evaluated in vitro. Anticoagulants (AC) used for plasma collection can negatively impact bacterial replication but their effect on $R$. equi growth has not been evaluated. The aim of this study was to establish the effect that AC routinely used in veterinary medicine ( $A C D, K_{2} E D T A$, Li Heparin, and $\mathrm{Na}$ Citrate) have on in vitro $R$. equi growth. To assess this, in vitro assays commonly used to test HIP efficacy (direct effect on microorganism and macrophage infection), were performed using each AC and non-treated bacteria.
\end{abstract}

Results: There was no direct effect of ACD, Li Heparin or Na Citrate on R. equi growth. These AC significantly $(p<0.05)$ delayed growth for $12 \mathrm{~h}$ following opsonization. The number of $R$. equi colonies after macrophage infection was significantly $(p<0.05)$ lower $72 \mathrm{~h}$ post-opsonization with $\mathrm{Na}$ Citrate. $\mathrm{K}_{2}$ EDTA inhibited the formation of $R$. equi colonies by $12 \mathrm{~h}$ in all the assays. In conclusion, AC should be taken into consideration when interpreting in vitro results as their negative effect on bacterial growth may be mistakenly interpreted as HIP efficacy. ACD and Li Heparin appear more appropriate for the selected assays.

Keywords: Rhodococcus equi, Prescotella equi, Anticoagulants, Plasma, EDTA, Citrate, Macrophages

\section{Introduction}

Rhodococcus equi ( $R$. equi) is a Gram-positive bacterium that infects macrophages and causes bronchopneumonia $[1,2]$ and extrapulmonary disease $[3,4]$ in young foals worldwide. There is no vaccine against this condition; therefore, $R$. equi-specific hyperimmune plasma of equine origin (HIP) is administered to neonatal foals for prophylaxis. However, the protective mechanism of HIP is poorly understood [5-7]. The in vivo study of HIP is complicated by the fact that animals such as mice [8] and guinea pigs [9] don't develop typical lesions after

\footnotetext{
*Correspondence: macarena@wsu.edu

${ }^{1}$ Department of Veterinary Clinical Sciences, College of Veterinary

Medicine, Washington State University, Pullman, WA, USA

Full list of author information is available at the end of the article
}

experimental infection. As a result, in vitro assays are used to investigate the effect that HIP has on $R$. equi infection of macrophages $[10,11]$.

Multiple in vitro studies have evaluated the effect that HIP has on $R$. equi intracellular survival [10, 12, 13]; however, little attention has been paid to the type of anticoagulant $(\mathrm{AC})$ used to collect these plasma products. Sodium citrate (Na Citrate) is commonly used to collect large volumes of plasma but other $\mathrm{AC}$ such as acid citrate dextrose $(\mathrm{ACD})$, ethylenediaminetetraacetic acid (EDTA), and lithium heparin (Li Heparin) are also used. These compounds prevent blood coagulation by different mechanisms and in addition, some directly compromise in vitro growth of microorganisms [14-16]. However, the effect that $\mathrm{AC}$ may have on $R$. equi in vitro assays has not been evaluated. Failure to recognize these effects can 
lead to misinterpretation of the data and result in inappropriate estimation of product efficacy [14] jeopardizing patient safety. The objective of this study was to evaluate the effect that routinely used AC namely ACD, $\mathrm{K}_{2}$ EDTA, $\mathrm{Li}$ Heparin and $\mathrm{Na}$ Citrate have on commonly performed $R$. equi in vitro assays.

\section{Main text \\ Methods \\ Bacterial strain and growth}

Pathogenic R. equi \#ATCC $103^{+}$expressing $g f p$ gene [17] was cultured from glycerol stock on brain heart infusion (BHI; BD Difco, MD) agar plates at $37^{\circ} \mathrm{C}$ for $48 \mathrm{~h}$. A colony was inoculated in $5 \mathrm{~mL}$ of $\mathrm{BHI}$ following incubation $\left(37^{\circ} \mathrm{C}\right.$ for $\left.18 \mathrm{~h}\right)$. Concentration was estimated using optical density and confirmed by dilution plating and colony forming unit (CFU) counts after $48 \mathrm{~h}$.

\section{Cell culture}

Murine macrophages RAW264.7 (ATCC TIB-71, MD) were irradiated as previously described [18] to prevent cell multiplication. Cells were maintained in Dulbecco's Modified Eagle Medium (DMEM; Gibco, NY) containing $10 \%$ fetal bovine serum, and $1 \%$ penicillin-streptomycin (Sigma Aldrich, MO).

\section{Anticoagulant effect on R. equi growth}

Media (BHI) was added to Vacutainer tubes ${ }^{\circledR}$ (BD, NJ) containing $\mathrm{K}_{2} \mathrm{EDTA}$, Li Heparin, Na Citrate or ACD (1:7 AC:BHI). Thereafter, $0.5 \mathrm{~mL}$ of BHI-AC was mixed with $1.5 \mathrm{~mL}$ of BHI containing $1-3 \times 10^{4} \mathrm{CFU}$ of $R$. equi. Tubes were incubated at $37^{\circ} \mathrm{C}$ and $\mathrm{CFU} / \mathrm{mL}$ were calculated at $0,8,12,18,24$, and $32 \mathrm{~h}$ post-incubation (time to stationary phase) by serial plate dilution. R. equi was also grown in BHI without AC (positive control) and in BHI/ PBS (1:7) to account for dilution.

\section{Plasma effect on R. equi growth}

Plasma from two healthy horses from the Washington State University research herd was collected using Vacutainer $^{\circledR}$ tubes containing the AC above mentioned. Serum was also collected. Briefly, whole blood was collected in the tubes and centrifuged at $500 \times \mathrm{g} 15 \mathrm{~min}$ to allow separation of the plasma/serum from the red blood cells. Plasma/serum $(0.5 \mathrm{~mL})$ from each horse was mixed with $1.5 \mathrm{~mL}$ of BHI containing $1-3 \times 10^{4} \mathrm{CFU} R$. equi. Tubes were incubated at $37{ }^{\circ} \mathrm{C}$ and $\mathrm{CFU} / \mathrm{mL}$ were calculated at $0,6,12,18,24$, and $32 \mathrm{~h}$ post-incubation using serial dilution.

\section{R. equi opsonization}

Opsonization was performed as previously described [19]. Briefly, plasma and serum from 3 healthy horses from the WSU research herd was collected as described above and pooled. Each plasma/serum was mixed with BHI containing $1-3 \times 10^{6} \mathrm{CFU} / \mathrm{mL}$ of $R$. equi (v/v 1:3) for $30 \mathrm{~min}$ at $37^{\circ} \mathrm{C} 60 \mathrm{rpm}$. Thereafter, bacteria were washed with PBS, resuspended in phagocytic media, and used for intracellular infections. Non-opsonized $R$. equi that underwent the same manipulation was also included.

\section{Intracellular assay}

Infections were performed as described before [10] with modifications. Briefly, RAW264.7 monolayers $\left(1 \times 10^{5}\right.$ cells/well) were incubated overnight on 24-well tissue culture plates (Eppendorf, Germany) and washed with warm PBS prior to infection. Phagocytic buffer containing opsonized or non-opsonized $R$. equi at multiplicity of infection of 20 was added to each well and cells were incubated $1 \mathrm{~h}$ at $37{ }^{\circ} \mathrm{C}$. Monolayers were then washed to remove unbound bacteria; and incubated $30 \mathrm{~min}$ for bound bacteria to be internalized. Media was replaced with complete DMEM (cDMEM) with $20 \mu \mathrm{g} / \mathrm{mL}$ of amikacin sulfate for $1 \mathrm{~h}$ to kill extracellular bacteria. Cells were then washed and incubated in CDMEM until lysis at $0,24,48$, and $72 \mathrm{~h}$ post-infection and detachment for fluorescence microscopy ( $24 \mathrm{~h}$ ). Lysis was achieved using saponin $0.1 \%$, scraping, microtube homogenizer and centrifugation $(10,000 \times g 10 \mathrm{~min})$. Bacterial growth was determined by dilution plating of lysates.

\section{Fluorescence microscopy}

Infected cells were detached using cell dissociation buffer (Thermo Fisher, MA) immediately $\left(\mathrm{T}_{0}\right)$ and $24 \mathrm{~h}$ after infection. Cells were stained with ProLong ${ }^{\mathrm{TM}}$ GoldAntifade-Mountant with DAPI (Invitrogen, CA). Three hundred macrophages were counted and the number of infected cells and cells with 10 or more bacteria were established using the ImageJ software (NIH, Bethsda, MD) as described before [10].

\section{Statistical analysis}

Data were analyzed using $\mathrm{R}$ studio statistical software (https://www.r-project.org/). Normality and variance were assessed with Shapiro-Wilks and Levene's tests respectively. For $\mathrm{CFU} / \mathrm{mL}$ data analysis was log transformed. Changes in CFU/mL for BHI and plasma assays were evaluated using repeated measures two-factor analysis of variance (ANOVA) with interaction using a random effect. Changes in intracellular $\mathrm{CFU} / \mathrm{mL}$ were evaluated using repeated measures two-factor ANOVA. Post-Hoc tests were conducted using the Dunnett's test. The experiments were performed in duplicates and repeated on 3 different days. Significance was set up at $\mathrm{p}<0.05$. 


\section{Results}

\section{Anticoagulant effect on R. equi growth}

$R$. equi concentration was not different between groups at $\mathrm{T}_{0}$. CFU/mL significantly $(\mathrm{p}<0.001)$ increased $8 \mathrm{~h}$ post-inoculation and at every timepoint thereafter in BHI and BHI/PBS. Similar growth overtime was observed in tubes with ACD, Li Heparin and $\mathrm{Na}$ Citrate. No significant differences were observed in the number of CFU/ $\mathrm{mL}$ between these groups at any time. In contrast, $R$. equi cultured in $\mathrm{K}_{2}$ EDTA tubes had significantly $(\mathrm{p}<0.001)$ lower $\mathrm{CFU} / \mathrm{mL}$ by $8 \mathrm{~h}$ post-inoculation. Moreover, there were no visible CFU by $18 \mathrm{~h}$ post-inoculation; thus, CFU/ $\mathrm{mL}$ were significantly $(\mathrm{p}<0.001)$ lower than the rest of the groups at all time points thereafter (Fig. 1).

\section{Plasma effect on R. equi growth}

R. equi CFU/mL significantly $(\mathrm{p}<0.001)$ increased by $6 \mathrm{~h}$ post-inoculation in $\mathrm{BHI}$ and $\mathrm{BHI} / \mathrm{PBS}$. R. equi cultured in serum or plasma collected using ACD, Li Heparin, and $\mathrm{Na}$ Citrate grew significantly $(\mathrm{p}<0.05)$ at every time point from $12 \mathrm{~h}$ post-inoculation. There was no significant difference in CFU/mL between these groups at any time. Tubes incubated with plasma containing $\mathrm{K}_{2}$ EDTA had significantly $(\mathrm{p}<0.001)$ lower $\mathrm{CFU} / \mathrm{mL}$ by $6 \mathrm{~h}$ post-inoculation and had no visible CFU by $18 \mathrm{~h}$ post-inoculation. Thus, CFU/mL were significantly $(\mathrm{p}<0.001)$ lower than the rest of the groups at all time points thereafter (Fig. 2).

\section{Intracellular assay}

At $\mathrm{T}_{0}$, there were no differences in $\mathrm{CFU} / \mathrm{mL}$ between groups. Non-opsonized $R$. equi (CFU/mL) grew significantly $(\mathrm{p}=0.0082)$ overtime inside macrophages after $24 \mathrm{~h}$ post-infection. While $R$. equi opsonized with serum or plasma collected with ACD, Li Heparin, and $\mathrm{Na}$ Citrate, grew significantly $(\mathrm{p}<0.001)$ inside macrophages by 48 and $72 \mathrm{~h}$ post-infection; growth was significantly $(p=0.02)$ lower in Na Citrate by $72 \mathrm{~h}$. In contrast, bacteria opsonized with $\mathrm{K}_{2}$ EDTA displayed no growth overtime inside macrophages at any of the time points evaluated. Therefore, CFU/mL were significantly $(\mathrm{p}<0.001)$ lower in $\mathrm{K}_{2}$ EDTA than in the other groups at 24, 48, and $72 \mathrm{~h}$ post-infection (Fig. 3 ).

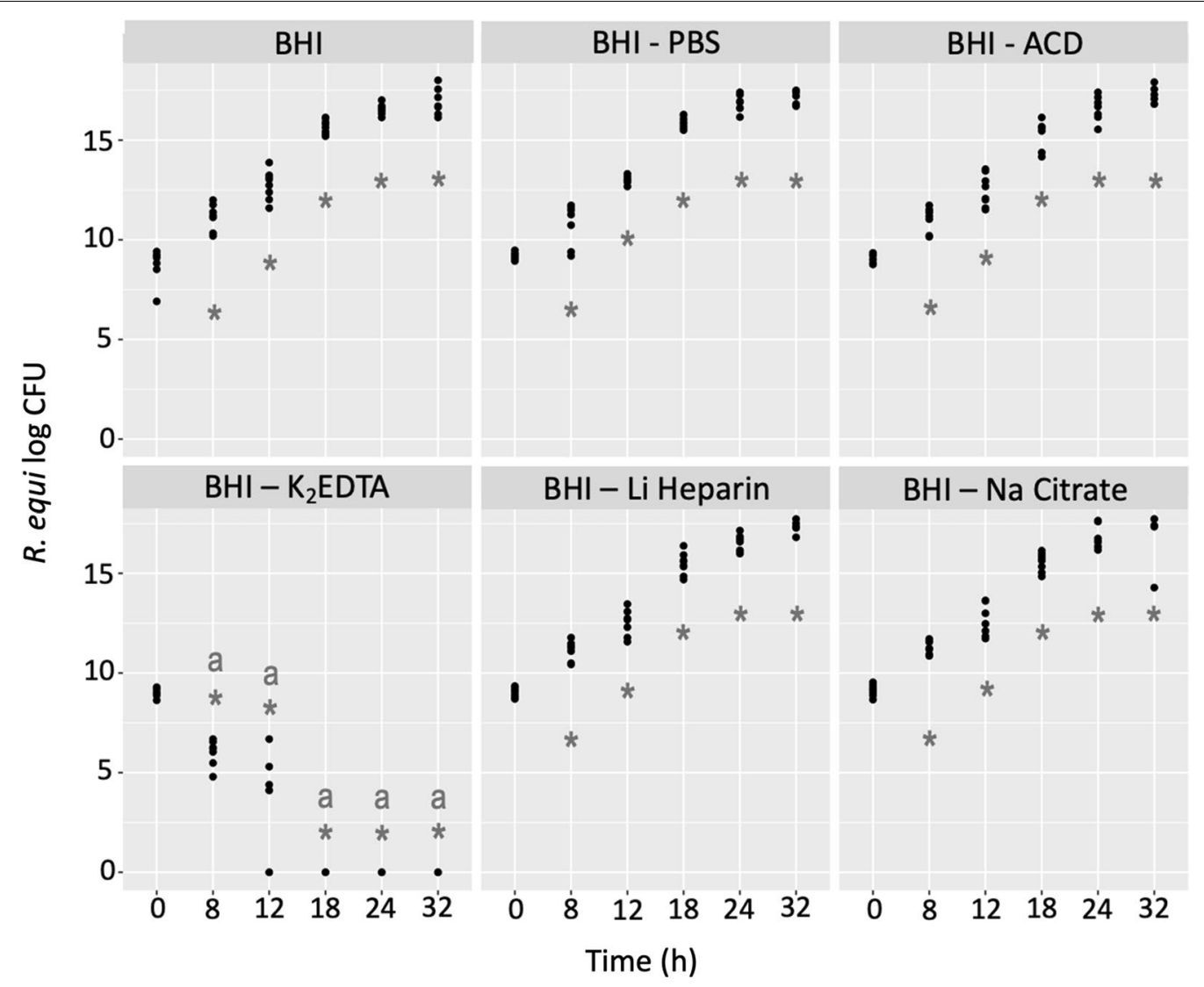

Fig. 1 R. equi (log CFU/mL) after $0.5 \mathrm{~mL}$ of plasma collected with different AC (ACD, $\mathrm{K}_{2} E D T A$, Li Heparin, Na Citrate) was mixed with $1.5 \mathrm{~mL}$ of $B H$ containing $1-3 \times 10^{4} \mathrm{CFU}$ of $R$. equi for $32 \mathrm{~h}$ at $37^{\circ} \mathrm{C}$. CFU/mL were counted immediately after mixing $\left(\mathrm{T}_{0}\right)$ and $8,12,18,24$, and $32 \mathrm{~h}$ thereafter. $\mathrm{BHI}$, and BHI/PBS were added as controls. Asterisks $\left.{ }^{*}\right)$ indicate significant change in CFU/mL from $\mathrm{T}_{0}(\mathrm{p}<0.001)$ by group. Letters indicates significant $(p<0.001)$ differences in CFU/mL between groups at a specific timepoint 


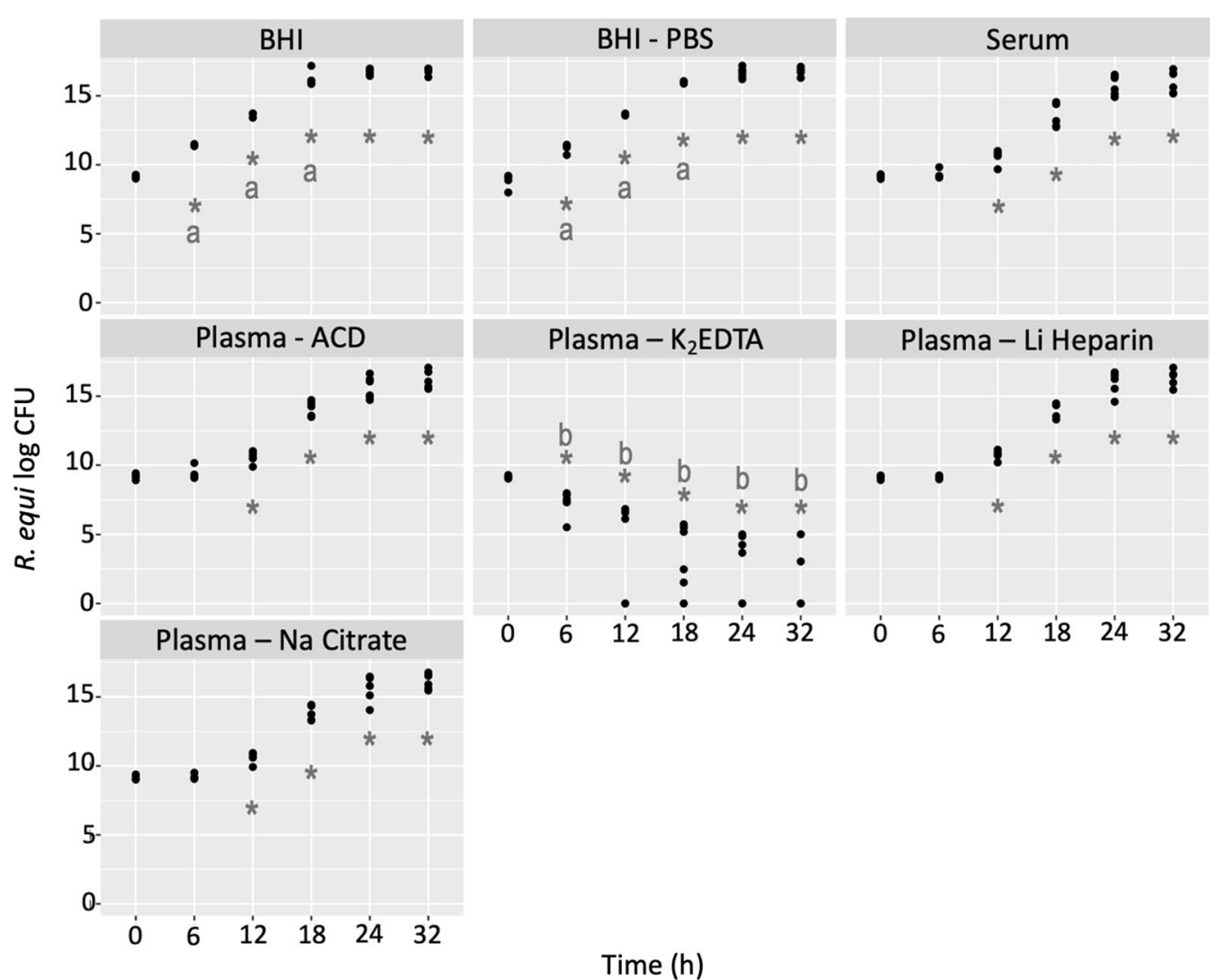

Time (h)

Fig. 2 R. equi (log CFU/mL) after $0.5 \mathrm{~mL}$ of serum or plasma collected with different AC (ACD, $\mathrm{K}_{2}$ EDTA, Li Heparin, and Na Citrate) were mixed with $1.5 \mathrm{~mL}$ of $\mathrm{BH}$ containing $1-3 \times 10^{4} \mathrm{CFU} / \mathrm{mL}$ of $R$. equi for $32 \mathrm{~h}$ at $37^{\circ} \mathrm{C}$. CFU/mL were counted immediately after mixing $\left(\mathrm{T}_{0}\right)$ and $6,12,18,24$, and $32 \mathrm{~h}$ thereafter. $\mathrm{BHI}$, and BHI/PBS were added as controls. Asterisks $\left(^{*}\right)$ indicate significant change in $\mathrm{CFU} / \mathrm{mL}$ from $\mathrm{T}_{0}(\mathrm{p}<0.05)$ by group. Different letters denote significant $(p<0.05)$ differences in $C F U / m L$ between groups at a specific timepoint

There were no significant differences in the number of infected cells per 300 macrophages or in the number of macrophages infected with 10 or more $R$. equi at $\mathrm{T}_{0}$. $R$. equi opsonized with plasma collected with $\mathrm{K}_{2}$ EDTA had significantly $(\mathrm{p}=0.04)$ fewer macrophages infected with 10 or more bacteria $24 \mathrm{~h}$ post-inoculation.

\section{Discussion}

This study shows that the choice of AC significantly influences the results of the selected in vitro assays which are commonly used to study $R$. equi infection and the efficacy of HIP (Additional file 1: Figs. S1 and S2) [10-19, 23]. Overall, exposure of $R$. equi to $\mathrm{K}_{2}$ EDTA resulted in inhibition of CFU formation shortly after exposure; this was not observed when other AC were used. This is important as growth inhibition of $R$. equi is a desirable effect of HIP. Most of the published work evaluating in vitro $R$. equi growth does not report the type of AC used for plasma collection. Therefore, it is difficult to establish if the effect of the AC was taken into consideration at the time of results interpretation.
Failure to do so has led to equivocal efficacy reports in humans [14]. ACD and heparin did not have any significant impact on any of the assays evaluated.

As described for other Gram-negative and positive bacteria $[14,15,20,21]$, direct exposure to $\mathrm{K}_{2} \mathrm{EDTA}$ in broth resulted in complete inhibition of CFU by $18 \mathrm{~h}$. This is likely the result of the strong $\mathrm{Ca}^{2+}$ and $\mathrm{Mg}^{2+}$ chelating capacity of $\mathrm{K}_{2}$ EDTA increasing cell permeability and fragility which may lead to cell lysis [16]. Interestingly, a similar effect was not observed when the other citrate-based AC (Na Citrate and ACD) were used. Citrate-based anticoagulants prevent coagulation by chelating ionized calcium present in the blood to form non-ionized calcium-citrate complexes; however, their chelating effect is weaker than that of $\mathrm{K}_{2}$ EDTA, especially for $\mathrm{Mg}^{2+}[15,22]$. Heparin, an $\mathrm{AC}$ that inhibits coagulation mainly by enhancing the activity of antithrombin III, didn't show a direct effect on $R$. equi growth. This was expected as the authors could find no evidence that antithrombin is relevant to bacterial survival. 


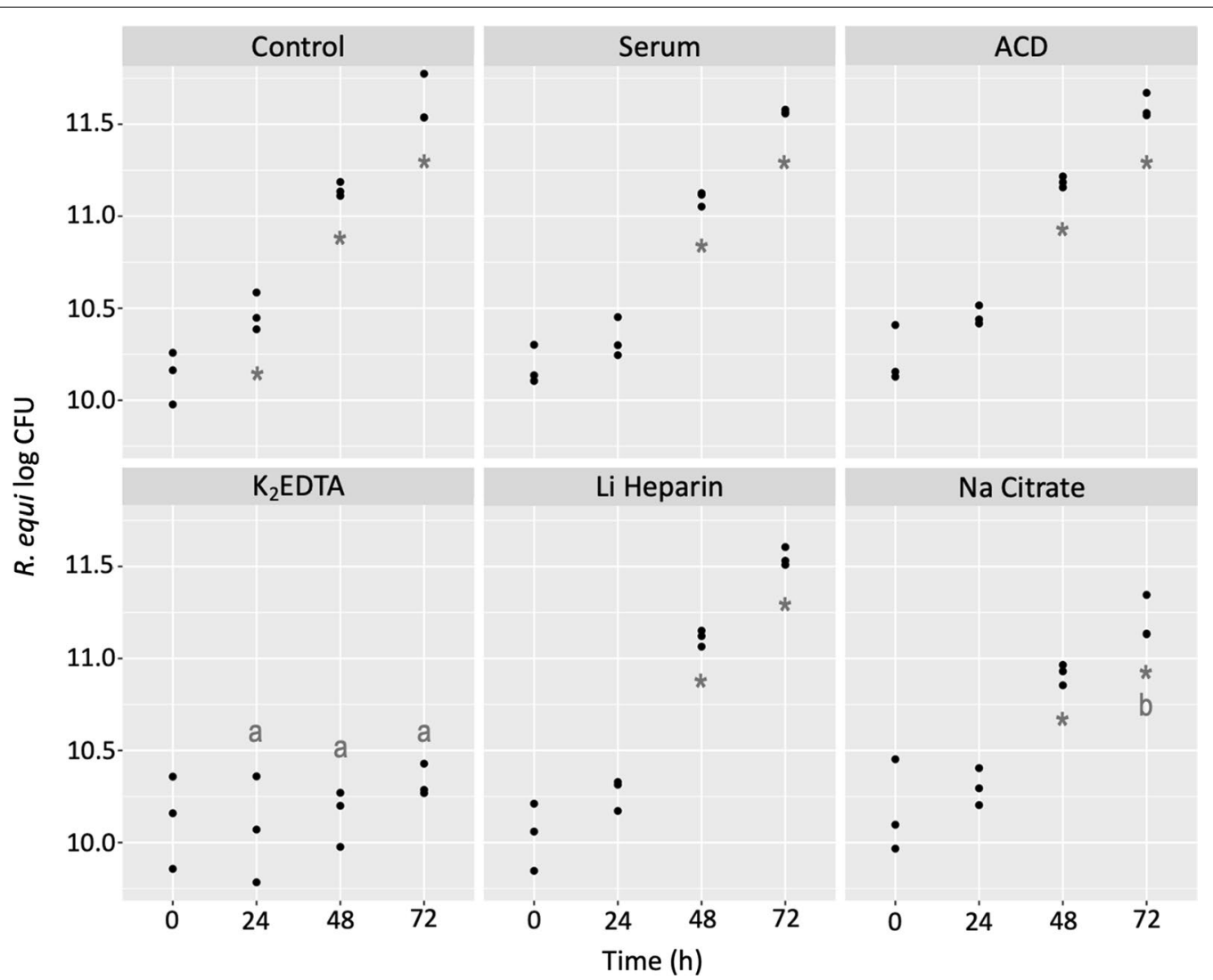

Fig. 3 R. equi (log CFU/mL) after RAW264.7 cells were infected with non-opsonized (control) or opsonized (serum or plasma collected with $A C D$, $\mathrm{K}_{2}$ EDTA, Li Heparin, or Na Citrate) bacteria and lysed at $0,24,48$, and $72 \mathrm{~h}$ post-infection. Asterisks $\left(^{*}\right)$ indicate significant growths from $\mathrm{T}_{0}(\mathrm{p}<0.05)$. Different letters denote significant $(p<0.05)$ differences in $C F U / m L$ between groups at a specific timepoint

In addition to the effects seen with $\mathrm{K}_{2} \mathrm{EDTA}$, there was a bacteriostatic effect observed the first $12 \mathrm{~h}$ post-inoculation with the other plasmas and serum. This is likely the effect of the antimicrobial proteins normally present in these bodily fluids as serum was collected without AC [23].

Intracellular infections were performed using murine macrophages which have been used to study $R$. equi infection [10, 13, 24]. Opsonization of $R$. equi with $R$. equi-specific antibodies increases microorganism uptake by Fcy receptors of macrophages and enhances their oxidative burst $[19,25,26]$. Moreover, plasma and serum boost $R$. equi killing by enhancing phagosomelysosome fusion [27]. Na Citrate significantly decreased intracellular $R$. equi growth overtime suggesting that sufficient chelation of calcium to weaken cell wall occurs [16], although other mechanism of growth inhibition such as hyperosmolarity of the solution $[28,29]$ and partial complement inhibition [15] can't be ruled out. Interestingly, opsonization with plasma collected with $\mathrm{K}_{2}$ EDTA resulted in intracellular $R$. equi growth inhibition but not death in the $72 \mathrm{~h}$ period studied. EDTA partially decreased bacterial deposition of C5b9, a multimer that mediates bacterial killing on Neisseria meningitidis [15]. Others have shown that EDTA inhibited CR3-mediated binding on RAW264.7 cells, decreasing phagocytosis of the Gram-negative bacterium Borrelia burgdorferi [30]. The exact mechanism for the lack of $R$. equi death inside macrophages in our study remains to be determined.

There were no significant differences in the number of infected cells per 300 macrophages or number of macrophages with 10 or more $R$. equi immediately postinfection suggesting that $\mathrm{AC}$ do not affect the initial $R$. equi uptake by macrophages. The number of macrophages containing 10 or more bacteria after $24 \mathrm{~h}$ was significantly lower when EDTA was used. This likely reflects the direct effect of $\mathrm{K}_{2}$ EDTA on $R$. equi growth. Unfortunately, bacterial fluorescence was not reliable past $24 \mathrm{~h}$ (data not shown) which limited our ability to evaluate cell replication past this point [31]. Thus, only CFU data are reported for subsequent timepoints. 


\section{Conclusion}

Anticoagulants significantly influenced the selected $R$. equi in vitro assays. Specifically, $\mathrm{K}_{2}$ EDTA inhibited CFU formation and resulted in intracellular growth inhibition, whereas $\mathrm{Na}$ Citrate delayed intracellular growth. Failure to recognize these effects can lead to misinterpretation of the data and inappropriate estimation of product efficacy. The use of ACD and Li Heparin appears to be more appropriate choices for the selected in vitro assays.

\section{Limitations}

- Only one strain has been used for this study ( $R$. equi 103 s-gfp).

\section{Abbreviations}

AC: Anticoagulant; ACD: Acid citrate dextrose; ANOVA: Analysis of variance; CDMEM: Complete DMEM; CFU: Colony forming units; EDTA: Ethylenediaminetetraacetic acid; HIP: Rhodococcus equi- Hyperimmune plasma; Li Heparin: Lithium heparin; Na Citrate: Sodium citrate; R. equi: Rhodococcus equi.

\section{Supplementary Information}

The online version contains supplementary material available at https://doi. org/10.1186/s13104-022-05933-4.

Additional file 1: Figure S1. R. equi (log CFU/mL) after either $0.5 \mathrm{~mL}$ of $R$ equi-specific HIP (HIP-Re) or hyperimmune plasma not specific for $R$. equi (HIP-NoRe) were mixed with $1.5 \mathrm{~mL}$ of $\mathrm{BH}$ l containing $1-3 \times 10^{4} \mathrm{CFU} / \mathrm{mL}$ of $R$. equi for $36 \mathrm{~h}$ at $37^{\circ} \mathrm{C}$. All plasmas were collected using sodium citrate. CFU/mL were counted immediately after mixing (T0) and 12, 18 and 24 $\mathrm{h}$ thereafter. $\mathrm{BHI}$ was added as control. Statistical significance between groups is noted in the graph. Figure S2. R. equi (log CFU/mL) after $1 \times 10^{5}$ RAW264.7 cells were infected with non-opsonized (control) or opsonized with R. equi-specific HIP (HIP-Re) or serum R. equi at a MOI 20 for $1 \mathrm{~h}$. Infected cells were lysed at 0, 24, 48, and $72 \mathrm{~h}$ post-infection, were plated in $\mathrm{BHI}$ agar plates and bacterial colonies were counted $48 \mathrm{~h}$ later. Statistical significance between groups is noted in the graph.

\section{Acknowledgements}

Not applicable.

\section{Authors' contributions}

Study was designed by AAR and MGS. Data collection was conducted by AAR, DCP, and AJK. Data analysis and statistics were done by AAR, RKS, CK, and MGS. Preparation of manuscript was done by AAR and MGS. All authors read and approved the final manuscript.

\section{Funding}

This study was funded by intramural Grant from the Department of Veterinary Clinical Sciences at Washington State University.

\section{Availability of data and materials}

Data is available upon request. Please contact Dr Macarena G. Sanz (macarena@wsu.edu).

\section{Declarations}

Ethics approval for consent to participate

The horses used for this study belong to Washington State University research herd. Procedures for blood collection were reviewed and approved by the WSU Institutional Animal Care and Use Committee (ASAF \# 6522).

\section{Consent for publication}

Not applicable.

\section{Competing interests}

Not applicable.

\section{Author details}

${ }^{1}$ Department of Veterinary Clinical Sciences, College of Veterinary Medicine, Washington State University, Pullman, WA, USA. ${ }^{2}$ Department of Mathematics, Washington State University, Pullman, WA, USA.

Received: 4 June 2021 Accepted: 28 January 2022

Published online: 14 February 2022

\section{References}

1. Takai S, lie M, Watanabe Y, Tsubaki S, Sekizaki T. Virulence-associated 15- to 17-kilodalton antigens in Rhodococcus equi: temperature-dependent expression and location of the antigens. Infect Immun. 1992;60(7):29957. https://doi.org/10.1128/IAl.60.7.2995-2997.1992.

2. Hondalus MK. Pathogenesis and virulence of Rhodococcus equi. Vet Microbiol. 1997;56(3-4):257-68. https://doi.org/10.1016/s0378-1135(97) 00094-1.

3. Reuss SM, Chaffin MK, Cohen ND. Extrapulmonary disorders associated with Rhodococcus equi infection in foals: 150 cases (1987-2007). J Am Vet Med Assoc. 2009;235(7):855-63. https://doi.org/10.2460/javma.235.7.855.

4. Sanz M, Loynachan A, Sun L, Oliveira A, Breheny P, Horohov DW. The effect of bacterial dose and foal age at challenge on Rhodococcus equi infection. Vet Microbiol. 2013;167(3-4):623-31. https://doi.org/10.1016/j. vetmic. 2013.09.018.

5. Becú T, Polledo G, Gaskin JM. Immunoprophylaxis of Rhodococcus equi pneumonia in foals. Vet Microbiol. 1997:56(3-4):193-204.

6. Sanz MG, Oliveira AF, Page A, Horohov DW. Administration of commercial Rhodococcus equi specific hyperimmune plasma results in variable amounts of IgG against pathogenic bacteria in foals. Vet Rec. 2014;175(19):485. https://doi.org/10.1136/vr.102594.

7. Kahn SK, Blodgett GP, Canaday NM, Bevevino KE, Rocha JN, Bordin Al, et al. Transfusion with $2 \mathrm{~L}$ of hyperimmune plasma is superior to transfusion of $1 \mathrm{~L}$ or less for protecting foals against subclinical pneumonia attributed to Rhodococcus equi. J Equine Vet Sci. 2019;79:54-8. https://doi. org/10.1016/j.jevs.2019.05.015.

8. Oliveira AF, Ruas LP, Cardoso SA, Soares SG, Roque-Barreira MC. Vaccination of mice with salmonella expressing VapA: mucosal and systemic Th1 responses provide protection against Rhodococcus equi infection. PLoS ONE. 2010:5(1): e8644. https://doi.org/10.1371/journal.pone.0008644.

9. Zink MC, Yager JA. Experimental infection of piglets by aerosols of Rhodococcus equi. Can J Vet Res. 1987;51(3):290-6.

10. Hondalus MK, Mosser DM. Survival and replication of Rhodococcus equi in macrophages. Infect Immun. 1994;62(10):4167-75.

11. Berghaus $L$, Giguère $S$, Sturgill TL. Effects of age and macrophage lineage on intracellular survival and cytokine induction after infection with Rhodococcus equi. Vet Immunol Immunopathol. 2014;160(1-2):41-50. https:// doi.org/10.1016/j.vetimm.2014.03.010.

12. von Bargen K, Scraba M, Krämer I, Ketterer M, Nehls C, Krokowski S, et al. Virulence-associated protein A from Rhodococcus equi is an intercompartmental pH-neutralising virulence factor. Cell Microbiol. 2019;21(1): e12958. https://doi.org/10.1111/cmi.12958.

13. Fernandez-Mora E, Polidori M, Lührmann A, Schaible UE, Haas A. Maturation of Rhodococcus equi-containing vacuoles is arrested after completion of the early endosome stage. Traffic. 2005;6(8):635-53. https://doi. org/10.1111/j.1600-0854.2005.00304.x. 
14. López-Medrano R, Guerra-Laso JM, López-Fidalgo E, Diez-Tascón C, García-García S, Blanco-Conde S, et al. Plasma contributes to the antimicrobial activity of whole blood against Mycobacterium tuberculosis. Innate Immun. 2016;22(7):557-66. https://doi.org/10.1177/1753425916663311.

15. Strobel $\mathrm{L}$, Johswich $\mathrm{KO}$. Anticoagulants impact on innate immune responses and bacterial survival in whole blood models of Neisseria meningitidis infection. Sci Rep. 2018;8(1):10225. https://doi.org/10.1038/ s41598-018-28583-8.

16. Umerska A, Strandh M, Cassisa V, Matougui N, Eveillard M, Saulnier P. Synergistic effect of combinations containing EDTA and the antimicrobial peptide AA230, an arenicin-3 derivative, on gram-negative bacteria. Biomolecules. 2018. https://doi.org/10.3390/biom8040122.

17. Burton AJ, Giguère S, Berghaus LJ, Hondalus MK, Arnold RD. Efficacy of liposomal gentamicin against Rhodococcus equi in a mouse infection model and colocalization with $R$. equi in equine alveolar macrophages. Vet Microbiol. 2015;176(3-4):292-300. https://doi.org/10.1016/j.vetmic. 2015.01.015.

18. Lee YJ, Han JY, Lee CG, Heo K, Park SI, Park YS, et al. Korean Red Ginseng saponin fraction modulates radiation effects on lipopolysaccharide-stimulated nitric oxide production in RAW264.7 macrophage cells. J Ginseng Res. 2014;38(3):208-14. https://doi.org/10.1016/j.jgr.2014.02.001.

19. Dawson DR, Nydam DV, Price CT, Graham JE, Cynamon MH, Divers TJ, et al. Effects of opsonization of Rhodococcus equi on bacterial viability and phagocyte activation. Am J Vet Res. 2011;72(11):1465-75. https://doi. org/10.2460/ajvr.72.11.1465.

20. Onoda T, Enokizono J, Kaya H, Oshima A, Freestone P, Norris V. Effects of calcium and calcium chelators on growth and morphology of Escherichia coli L-form NC-7. J Bacteriol. 2000;182(5):1419-22. https://doi.org/10. 1128/jb.182.5.1419-1422.2000

21. Root JL, Mclntyre OR, Jacobs NJ, Daghlian CP. Inhibitory effect of disodium EDTA upon the growth of Staphylococcus epidermidis in vitro: relation to infection prophylaxis of Hickman catheters. Antimicrob Agents Chemother. 1988;32(11):1627-31. https://doi.org/10.1128/aac.32.11.1627.

22. Bouchard J, Madore F. Role of citrate and other methods of anticoagulation in patients with severe liver failure requiring continuous renal replacement therapy. NDT Plus. 2009;2(1):11-9. https://doi.org/10.1093/ ndtplus/sfn184

23. Lagergard T, Frisk A, Purven M, Nilsson LA. Serum bactericidal activity and phagocytosis in host defence against Haemophilus ducreyi. Microb Pathog. 1995;18(1):37-51.

24. Darrah PA, Monaco MC, Jain S, Hondalus MK, Golenbock DT, Mosser DM. Innate immune responses to Rhodococcus equi. J Immunol. 2004;173(3):1914-24. https://doi.org/10.4049/jimmunol.173.3.1914.

25. Hietala SK, Ardans AA. Interaction of Rhodococcus equi with phagocytic cells from R. equi-exposed and non-exposed foals. Vet Microbiol. 1987;14(3):307-20. https://doi.org/10.1016/0378-1135(87)90118-0.

26. Rosales C. Fc receptors: cell activators of antibody functions. Adv Biosci Biotechnol. 2013:4:21-33.

27. Cauchard J, Sevin C, Ballet JJ, Taouji S. Foal lgG and opsonizing antiRhodococcus equi antibodies after immunization of pregnant mares with a protective VapA candidate vaccine. Vet Microbiol. 2004;104(1-2):73-81. https://doi.org/10.1016/j.vetmic.2004.09.006.

28. Ash SR, Mankus RA, Sutton JM, Criswell RE, Crull CC, Velasquez KA, et al. Concentrated sodium citrate (23\%) for catheter lock. Hemodial Int. 2000:4(1):22-31. https://doi.org/10.1111/hdi.2000.4.1.22.

29. Yon CK, Low CL. Sodium citrate $4 \%$ versus heparin as a lock solution in hemodialysis patients with central venous catheters. Am J Health Syst Pharm. 2013;70(2):131-6. https://doi.org/10.2146/ajhp120300.

30. Hawley KL, Olson CM, Iglesias-Pedraz JM, Navasa N, Cervantes JL, Caimano MJ, et al. CD14 cooperates with complement receptor 3 to mediate MyD88-independent phagocytosis of Borrelia burgdorferi. Proc Natl Acad Sci U S A. 2012;109(4):1228-32. https://doi.org/10.1073/pnas. 1112078109.

31. Ward WW, Bokman SH. Reversible denaturation of Aequorea green-fluorescent protein: physical separation and characterization of the renatured protein. Biochemistry. 1982;21(19):4535-40. https://doi.org/10.1021/ bi00262a003.

\section{Publisher's Note}

Springer Nature remains neutral with regard to jurisdictional claims in published maps and institutional affiliations.
Ready to submit your research? Choose BMC and benefit from:

- fast, convenient online submission

- thorough peer review by experienced researchers in your field

- rapid publication on acceptance

- support for research data, including large and complex data types

- gold Open Access which fosters wider collaboration and increased citations

- maximum visibility for your research: over $100 \mathrm{M}$ website views per year

At BMC, research is always in progress.

Learn more biomedcentral.com/submissions 